\title{
GABAergic and nitriergic influence in antianxiety-like Activity of Garlic in Mice
}

\author{
Neeraj Gilhotra ${ }^{1 *}$, Dinesh Dhingra ${ }^{2}$ \\ ${ }^{1}$ Department of Pharmaceutical Sciences Maharshi Dayanand University Rohtak-124001, Haryana, India. \\ ${ }^{2}$ Department of Pharmaceutical Sciences Guru Jambheshwar University of Science and Technology, Hisar-125001, Haryana, India.
}

\section{ARTICLE INFO}

Article history:

Received on: 15/02/2016

Revised on: 10/03/2016

Accepted on: 26/03/2016

Available online: 30/04/2016

Key words:

Aminoguanidine, anxiety,

GABA, garlic, nitric oxide.

\begin{abstract}
Objectives: To investigate the GABAergic and nitriergic mechanism involved in the anxiolytic-like profile of ethanolic extract of garlic (GE).

Materials and Methods: Male Swiss albino mice were employed in the present study. Stress was produced in mice by immobilizing them for $6 \mathrm{~h}$. Elevated plus maze, light/dark box and social interaction test were used for the assessment of anxiety in mice. Concentrations of GABA in brain and nitrite level in plasma were estimated to determine the possible involvement of GABAergic and nitriergic mechanisms in the anxiolytic profile of GE. Results: The present study showed that the GE produced significant antianxiety- like activity in unstressed and stressed mice. In unstressed mice, GE significantly increased GABA levels, but could not produce any change in nitrite levels. Meanwhile, in stressed mice, GE significantly increased GABA levels along with a significant decrease in nitrite levels. Pre-treatment with aminoguanidine, an inducible nitric oxide synthase inhibitor, significantly enhanced the anxiolytic-like activity of GE, as compared to GE and aminoguanidine alone in stressed mice, but not in unstressed mice. On the other hand, pretreatment with 7-nitroindazole, a neuronal nitric oxide synthase inhibitor, did not produce any significant change in antianxiety- like activity of GE in unstressed as well as stressed mice.

Conclusion: It has been concluded that the garlic may possess anxiolytic- like activity and possess NOS inhibiting property in stressed mice, which may add to its status to be used in stress-induced anxiety conditions.
\end{abstract}

\section{INTRODUCTION}

Stress can influence the neurobehavioral profile and precipitate an anxiety-like syndrome (Esch et al., 2002; Masood et al., 2003). Immobilization stress (60 and $120 \mathrm{~min}$ ) has been reported to enhance anxious behavior in rodents (Heinrichs et al., 1994). Acute (6h) stress activates nitric oxide synthase (NOS) and enhance anxiety in rodents (Madrigal et al., 2002; Sevgi et al., 2006; Sharma et al., 2011). Stressor used in the present study (6h immobilization) has been found to increase TNF- $\alpha$ levels. This increase in TNF- $\alpha$ level is observed to underlie NF-кB activation and iNOS expression in brain cortex after $6 \mathrm{~h}$ immobilization stress, as used in the present study (Madrigal et $a l ., 2002$ ). Activation of iNOS produces nitric oxide in the large quantity (Nagao et al., 2003). A transgenic mouse model, over-

\footnotetext{
* Corresponding Author

Email: neerajmdu[at]rediffmail.com
}

expressing gene for TNF- $\alpha$ has been shown to express excessive (pathological) anxiety in light and dark test (Fiore et al., 1998). Further, aminoguanidine, an inhibitor of iNOS, has been reported to attenuate $6 \mathrm{~h}$ immobilization-induced anxiety in mice (Gilhotra and Dhingra, 2009). Similarly, PDTC, an inhibitor of NF-кB, is observed to produce the antianxiety-like activity and enhance the antianxiety-like activity of aminoguanidine in the same $6 \mathrm{~h}$ immobilization model in mice (Gilhotra et al., 2010). Recently, inhibition of p38MAPK, a reported activator of NF-кB (BaezaRaja and Munoz-Canoves, 2004; Vercammen et al., 2008) has been found to restore the similar $6 \mathrm{~h}$ immobilization stressattenuated anti-anxiety effect of diazepam (Sharma et al., 2011). In addition to reported antianxiety-like activity of aminoguanidine (a selective iNOS inhibitor), non-selective inhibition of nitric oxide synthase by L-NAME (Sevgi et al., 2006; Kumar and Singh, 2008) and selective inhibition of other isoforms of NOS, relevant to pathological anxiety, i.e. neuronal form of NOS, by 7-nitroindazole 
(Pokk et al., 2001) have also found to produce antianxiety-like activities.

In addition to the above mentioned nitriergic mechanism of $6 \mathrm{~h}$ immobilization stress-induced anxiety, other mechanism may involve GABAergic modulation, as indicated by the observation that short term stress downregulate GABA pathways and reduce brain GABA content in mice (Manzanares et al., 2005). Involvement of GABAergic mechanism in $6 \mathrm{~h}$ immobilization stress- induced anxiety is strengthened by observations that anti-anxiety effect of diazepam, a potent GABAergic agonist, is suppressed in mice, exposed to $6 \mathrm{~h}$ immobilization stress. Both GABA and NO are actively involved in stress- induced behavioral processes including anxiety and their levels are observed to differ in unstressed and stressed mice (Gilhotra and Dhingra, 2009; Sharma et al., 2011). Recently, strong nitriergic influence over GABA has been observed, where SB-203580 (p38MAPK inhibitor) and PDTC (NF-кB inhibitor) were observed to restore the compromised anti-anxiety effect of diazepam in $6 \mathrm{~h}$ immobilization- stressed mice (Sharma et al., 2011).

Allium sativum Linn. (Family: Lilliaceae) is commonly known as garlic. Dried bulbs of garlic are incorporated in day to day practice as condiment/spice in food items. Garlic is endowed with several medicinal properties (Wealth of India, 1985). It has been reported to possess anti-stress, anti-ageing properties and reported to prevent progression of Alzheimer's disease (Ushijima et al., 1997; Chauhan and Sandoval 2007). Garlic and its constituents has demonstrated a wide spectrum of pharmacological properties; anti-oxidative (Ide et al., 1997; Imai et al., 1994), immunomodulating (Kyo et al., 2001), and hepato- protective (Wang et al., 1999; Sumioka et al., 2001) properties. Among its effects on brain, garlic has been reported to exert neuroprotection (Perez-Severiano et al., 2004; Saleem et al., 2006), prevent stressinduced organ degeneration (Saglam et al., 2006) and possess antistress property (Kyo et al., 1999). Recently, Dhingra and Kumar have reported anti-depressant property of garlic in mice (Dhingra and Kumar, 2008). Garlic significantly suppresses both mRNA and protein levels of iNOS (Schwartz et al., 2002). Further, garlic also inhibits nuclear factor kappa beta, a transcription activator of iNOS (Youn et al., 2005).

Therefore, in view of the existing relevant literature, we explored the potential of garlic extract for its anti-anxiety effect in behavioral paradigms, used to assess anxiety in mice, under unstressed and stressed conditions. Further, in view of relative roles of $\mathrm{NO}$ and GABA in stress-induced psychiatric changes including anxiety, biochemical estimations of plasma nitrite levels and brain GABA contents were also carried out to study the effect of different treatments on these parameters and resultant mice behavior in selected paradigms to assess anxiety.

\section{MATERIALS AND METHODS}

Animals

Swiss albino mice (male; 20-25 g) were employed in the present study. Animals were procured from Disease Free Small
Animal House, CCS Haryana Agricultural University, Hisar, Haryana, India. Animals were provided normal diet and tap water ad libitum and were exposed to $12 \mathrm{~h}$ light and $12 \mathrm{~h}$ dark cycle. The animals were acclimatized to the laboratory condition before experiments. Experimental protocol was approved by Institutional Animal Ethics Committee. Care of the animals was taken as per guidelines of the Committee for the Purpose of Control and Supervision of Experiments on Animals (CPCSEA), Ministry of Environment and Forests, Government of India.

\section{Collection of plant material and Preparation of extract from plant material}

Dried bulbs of Allium sativum Linn.was purchased from the local markets of Hisar, Haryana, India. About $200 \mathrm{~g}$ of chopped garlic extract were imbibed in $20 \% \mathrm{v} / \mathrm{v}$ ethanol for 10 days at ambient temperature and filtered. The crude extract was dried on water bath and kept in refrigerator till further use.

\section{Drugs}

Aminoguanidine (AG; Sigma Chemical Co., St. Louis, MO, USA), 7-nitroindazole (7-NI; Cayman Chemicals, USA), Diazepam (DZP; Calmpose injection, Ranbaxy Laboratories, Gurgaon, India) were used in the present study.

\section{Behavioral testing \\ Elevated plus maze}

The maze was a plus-shaped apparatus with an open roof, consisting of two $16 \times 5 \mathrm{~cm}$ open arms, and two $16 \times 5 \times 12 \mathrm{~cm}$ enclosed arms, and elevated at a height of $25 \mathrm{~cm}$. All testing was conducted between 0800 and 1700 hours in a quiet and dimly illuminated room. Each mouse was placed individually at the centre of elevated plus maze with its head facing towards an open arm and observed for $5 \mathrm{~min}$ to record the number of entries into open arm, closed arm and time spent in each arm (Kulkarni, 1999). A mouse was considered to have entered or spent time in an arm only when all four paws were in the respective arm. The time spent in the open arms and the number of open-arm entries were expressed as a percentage of total arm activity (open arm time / open arm time + closed arm time) $\times 100$, and total arm entries (open arm entries / open arm entries + closed arm entries) $\times 100$, respectively. A higher percentage of open arm time or open arm entries are taken as measures of anxiety reduction (anxiolysis).

In elevated plus maze test, percent time spent on the open arms was determined as follows:

$$
\%=100 \times \frac{\text { Number of seconds spent on open arms }}{300 \text { total seconds }(5 \mathrm{~min}) \text { observation time }}
$$

In elevated plus maze test, percent entries in open arms was determined as follows:

$$
\begin{aligned}
& \%=100 \times \text { Number of open arm entries } \\
& \text { Total entries in open and closed arms }
\end{aligned}
$$




\section{Light and dark box test}

The apparatus consisted a rectangular box $(45 \times 27 \times 27$ $\mathrm{cm}$ ), partitioned into two compartments (one light and one dark) connected by a $7.5 \times 7.5 \mathrm{~cm}$ opening in the wall between compartments. An animal was placed into the center of the light compartment and was observed for $5 \mathrm{~min}$ for time spent in open (white/light) compartment (Crawley and Goodwin, 1980). Percent time spent in the light compartment was determined as follows:

$$
\%=100 \times \frac{\text { Number of seconds spent in light compartment }}{300 \text { total seconds ( } 5 \text { min. observation time) }}
$$

\section{Social interaction test}

The social interaction arena was an open topped box $(22 \times 15 \times 12 \mathrm{~cm})$. Mice were isolated for $1 \mathrm{~h}$ before the test. After introduction to the test arena, mice were observed for cumulative time spent in genital investigation, sniffing a partner, climbing over and under, neck licking and boxing (File, 1980).

\section{Biochemical estimation of plasma nitrite}

For nitrite estimation, blood was withdrawn from tail vein of immobilized mice, immediately before setting the animal free and subjecting it to behavioral tests in all the groups. The sampling procedure was completed during immobilization to avoid the extra stress incurred upon mice during a new procedure of mouse immobilization for handling the tail of mice. Plasma was separated using refrigerated centrifuge at $2500 \mathrm{rpm}$ for $10 \mathrm{~min}$. It was stored in a refrigerator and processed for nitrite estimation within 24h (Gilhotra and Dhingra, 2009; 2011; Sharma et al., 2011). Plasma nitrite was measured by spectrophotometric assay based on Griess reaction (Green et al., 1982).

\section{Brain GABA Estimation}

Brain GABA content was estimated using method of Lowe et al., (1958).

\section{Experimental protocol}

Swiss albino mice (male; 20-25g; $\mathrm{n}=6$ each) were employed in the present study. Stress was produced in mice by immobilizing them for $6 \mathrm{~h}$ by taping all its four limbs and trunk on a wooden board (Gilhotra and Dhingra, 2009; 2011; Sharma et al., 2011; Gilhotra et al., 2010). Mice subjected to immobilization were called as stressed mice. Unstressed mice were exposed to elevated plus maze and light-dark test for normal duration (5 min), sufficient to assess the anxiety levels in rodents (Calatayud et al., 2004) and not subjected to immobilization and mentioned accordingly in the manuscript. All treatments (Vehicle, garlic extract $(20,40$ and $80 \mathrm{mg} / \mathrm{kg})$, aminoguanidine $(50 \mathrm{mg} / \mathrm{kg})$ (Gilhotra et al., 2010), 7-nitroindazole (20 mg/kg) (Gilhotra et al., 2010)) were administered intraperitoneally in a fixed volume of $1 \mathrm{ml} / 100 \mathrm{~g}$ body weight. For nitrite estimation, blood was withdrawn from tail vein of immobilized mice immediately before setting the animal free and subjecting it to behavioral tests in all the groups. The sampling procedure was completed during immobilization to avoid the extra stress incurred upon mice during an altogether new procedure of mouse immobilization for handling the tail of mice (Gilhotra and Dhingra, 2009; 2011; Sharma et al., 2011; Gilhotra et al., 2010). The apparatus was thoroughly cleaned using $5 \%$ ethanol before placing each mouse in the cage.

\section{Locomotor activity}

The effects of various treatments on spontaneous locomotor activity of animals were measured by using an actophotometer (INCO, Ambala, India). The data are presented as the number of counts, recorded by the apparatus as light ray is interrupted between light source and photo sensors, in response to animal movements. The locomotor activity scores for each animal were recorded for a period of $10 \mathrm{~min}$ before and after drug treatment.

\section{Statistical analysis}

All the results are expressed as Mean \pm S.E.M. Data were analyzed by analysis of variance (ANOVA) in Graph Pad Instat (GPIS) package, version 3.05. $\mathrm{p}<0.05$ was considered as significant.

\section{RESULTS}

In elevated plus maze, light-dark test and social interaction test, significant increase in percentage of time spent in open arms and number of open arm entries; significant increase in percentage of time spent in light compartment and significant increase in percentage of time spent in social interaction indicate anxiolytic-like effect respectively. On the other hand, significant decrease in various parameters of these behavioral models indicates anxiogenic effect.

In elevated plus maze test, $6 \mathrm{~h}$ immobilization significantly decreased percentage of time spent in open arms and number of open arm entries in mice as compared to vehicletreated unstressed mice. Diazepam (2 $\mathrm{mg} / \mathrm{kg})$ significantly increased percentage of time spent in open arms and number of open arm entries in unstressed mice, but not in stressed mice. GE $(80 \mathrm{mg} / \mathrm{kg})$ produced a significant antianxiety- like activity in unstressed as well as stressed mice. AG $(50 \mathrm{mg} / \mathrm{kg})$, an inhibitor of inducible isoform of nitric oxide synthase, per se, increased percentage of time spent in open arms and number of open arm entries in stressed mice, but not in unstressed mice. Pre-treatment with $\mathrm{AG}(50 \mathrm{mg} / \mathrm{kg})$ significantly enhanced antianxiety effect of GE (40 mg/kg), as compared to GE (40 mg/kg) as well as AG (50 $\mathrm{mg} / \mathrm{kg}$ ) alone in stressed mice, but not in unstressed mice. 7-NI (20 $\mathrm{mg} / \mathrm{kg}$ ), an inhibitor of neuronal isoform of nitric oxide synthase, per se, significantly produced anti-anxiety activity in unstressed mice, but not in stressed mice. Pre-treatment with 7-NI $(20 \mathrm{mg} / \mathrm{kg})$ did not produced any significant change in antianxiety- like activity of GE $(40 \mathrm{mg} / \mathrm{kg})$ in unstressed and stressed mice (Fig. 1 and 2).

In light-dark test, 6-h immobilization significantly decreased percentage of time spent by mice in light compartment as compared to vehicle- treated unstressed mice. Diazepam (2 $\mathrm{mg} / \mathrm{kg}$ ) significantly increased percentage of time spent by 


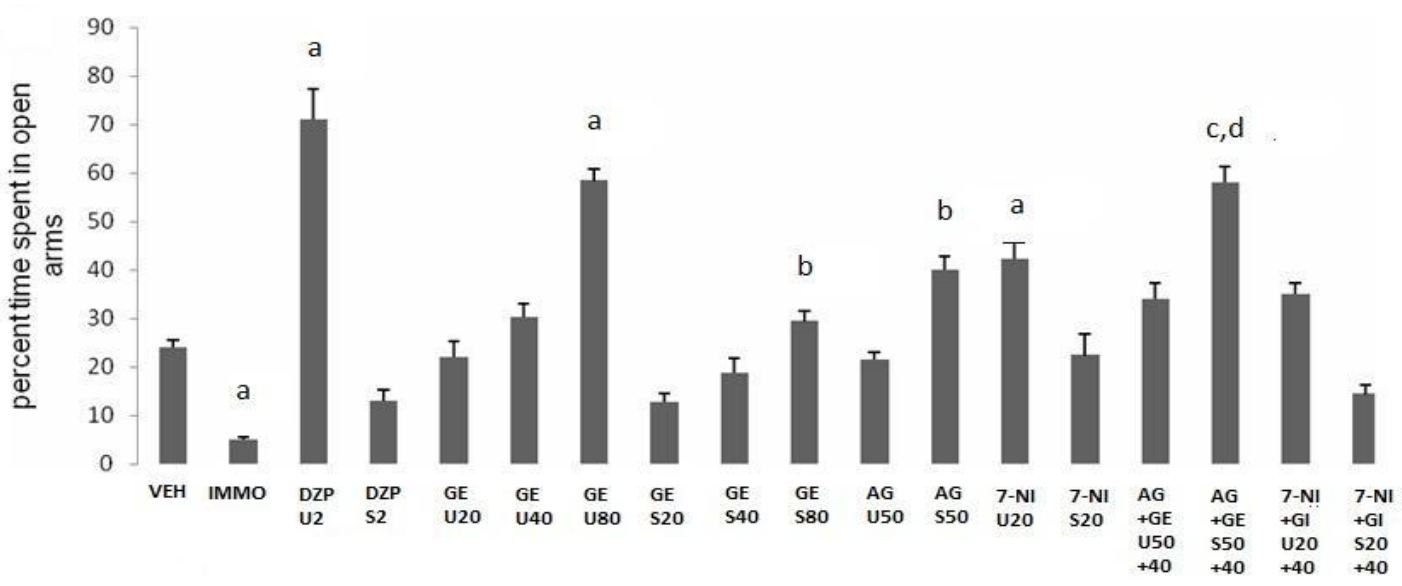

Fig. 1: Effect of different treatments on time spent by mice in open arms of plus maze.

$\mathrm{n}=6$ in each group. Values expressed as Mean \pm S.E., Data was analyzed by ANOVA followed by Tukey's Post hoc Test, $F(17,90)=34.96 ; \mathrm{P}<0.0001$, a $=$ significant difference from vehicle treated control group, $\mathrm{b}=$ significant difference from stressed mice, $\mathrm{c}, \mathrm{d}=$ significant difference from $\mathrm{GE}(40 \mathrm{mg} / \mathrm{kg})$ and $\mathrm{AG}$ $(50 \mathrm{mg} / \mathrm{kg})$ - treated stressed mice. Veh: vehicle; IMMO: immobilization; DZP(U): diazepam (unstressed); DZP(S): diazepam (stressed) GE(U): garlic extract (unstressed); GE(S): garlic extract (stressed); $\mathbf{A G ( U ) : ~ a m i n o g u a n i d i n e ~ ( u n s t r e s s e d ) ; ~} \mathbf{A G ( S ) : ~ a m i n o g u a n i d i n e ~ ( s t r e s s e d ) . ~ 7 - N I ( U ) : ~ 7 - n i t r o i n d a z o l e ~ ( u n s t r e s s e d ) ; ~}$ 7-NI(S): 7-nitroindazole (stressed). Doses mentioned are in $\mathrm{mg} / \mathrm{kg}$.

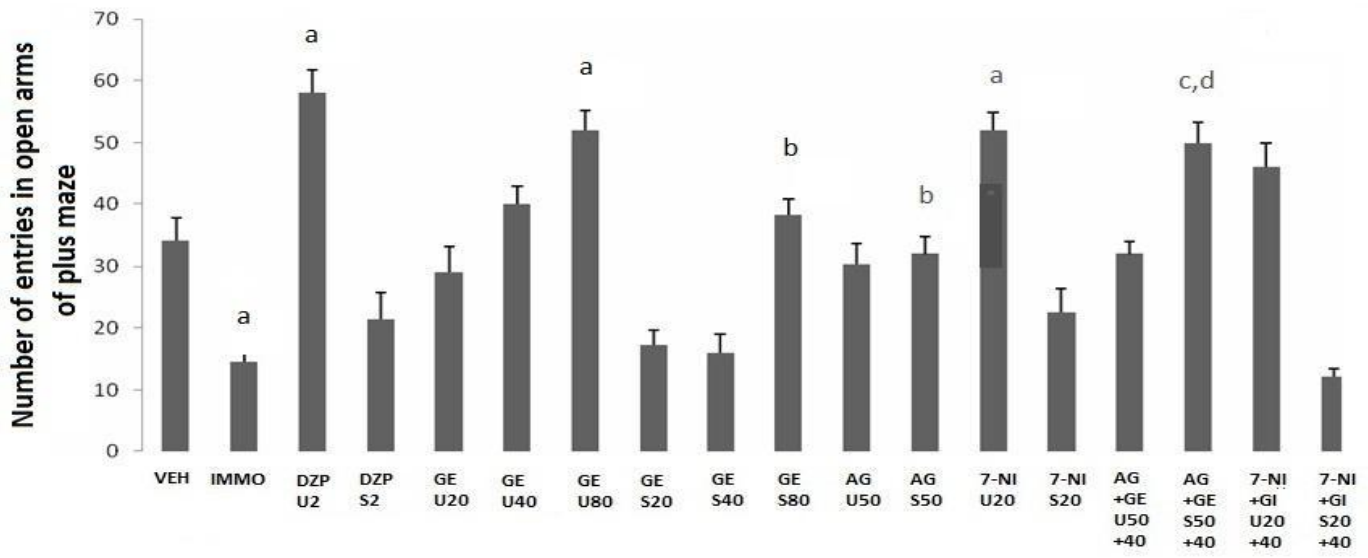

Fig. 2. Effect of different treatments on number of entries by mice in open arms of plus maze.

$\mathrm{n}=6$ in each group. Values expressed as Mean \pm S.E., Data was analyzed by ANOVA followed by Tukey's Post hoc Test, $F(17,90)=19.43 ; \mathrm{P}<0.0001$, a $=$ significant difference from vehicle treated control group, $\mathrm{b}=$ significant difference from stressed mice, $\mathrm{c}, \mathrm{d}=$ significant difference from $\mathrm{GE}(50 \mathrm{mg} / \mathrm{kg})$ and $\mathrm{AG}$ $(50 \mathrm{mg} / \mathrm{kg})$ - treated stressed mice. Veh: vehicle; IMMO: immobilization; DZP (U): diazepam (unstressed); DZP(S): diazepam (stressed) GE(U): garlic extract (unstressed); GE(S): garlic extract (stressed); $\mathbf{A G ( U ) : ~ a m i n o g u a n i d i n e ~ ( u n s t r e s s e d ) ; ~} \mathbf{A G ( S ) : ~ a m i n o g u a n i d i n e ~ ( s t r e s s e d ) . ~ 7 - N I ( U ) : ~ 7 - n i t r o i n d a z o l e ~ ( u n s t r e s s e d ) ; ~}$ 7-NI(S): 7-nitroindazole (stressed). Doses mentioned are in $\mathrm{mg} / \mathrm{kg}$.

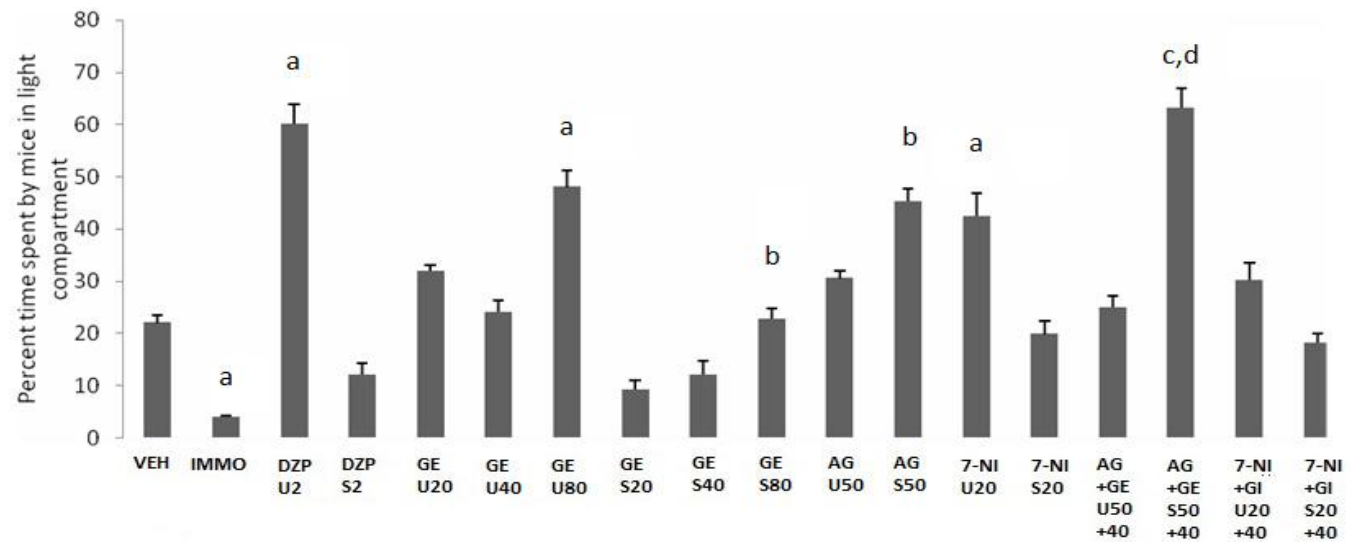

Fig. 3. Effect of different treatments on time spent by mice in light compartment of light/dark box.

$\mathrm{n}=6$ in each group. Values expressed as Mean \pm S.E., Data was analyzed by ANOVA followed by Tukey's Post hoc Test, $F(17,90)=43.04 ; \mathrm{P}<0.0001, \mathrm{a}=\mathrm{p}$ $<0.05$ significant difference from vehicle treated control group, $\mathrm{b}=\mathrm{p}<0.05$ significant difference from stressed mice, $\mathrm{c}, \mathrm{d}=\mathrm{p}<0.05$ significant difference from GE $(40 \mathrm{mg} / \mathrm{kg})$ and AG $(50 \mathrm{mg} / \mathrm{kg})$ - treated stressed mice. Veh: Vehicle; IMMO: immobilization; DZP (U): diazepam (unstressed); DZP(S): diazepam (stressed) GE(U): garlic extract (unstressed); GE(S): garlic extract (stressed); $\mathbf{A G ( U ) : ~ a m i n o g u a n i d i n e ~ ( u n s t r e s s e d ) ; ~} \mathbf{A G ( S ) : ~ a m i n o g u a n i d i n e ~ ( s t r e s s e d ) . ~ 7 - ~}$ NI(U): 7-nitroindazole (unstressed); 7-NI(S): 7-nitroindazole (stressed). Doses mentioned are in mg/kg. 


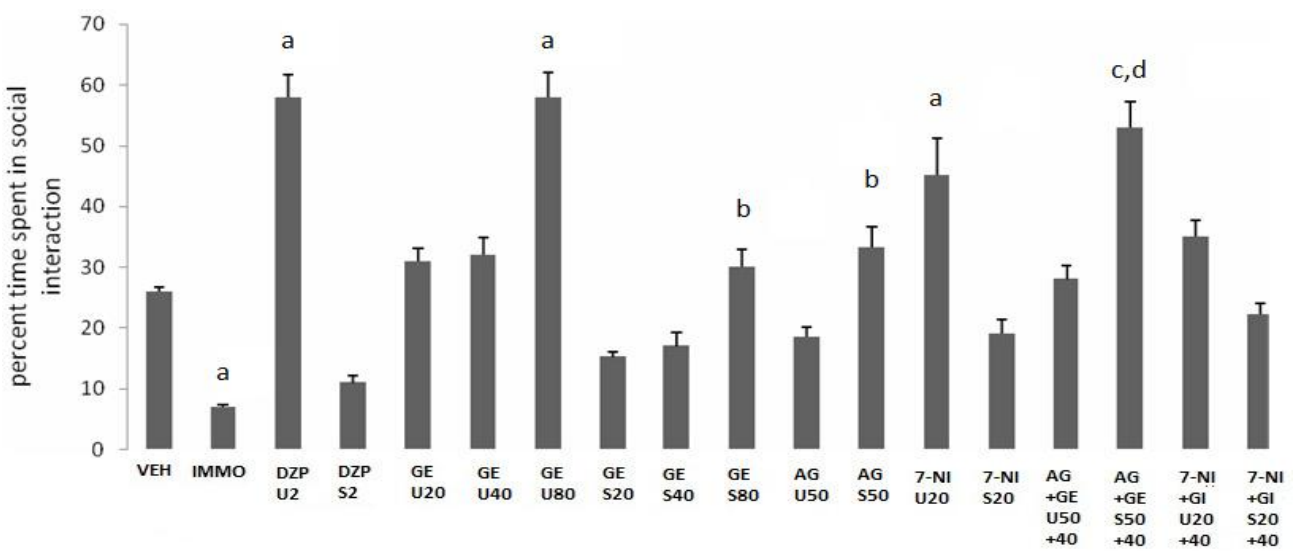

Fig. 4: Effect of different treatments on time spent by mice in social interaction.

$\mathrm{n}=6$ in each group. Values expressed as Mean \pm S.E., Data was analyzed by ANOVA followed by Tukey's Post hoc Test, $F(17,90)=34.39 ; \mathrm{P}<0.0001$, a $=\mathrm{p}$ $<0.05$ significant difference from vehicle treated control group, $\mathrm{b}=\mathrm{p}<0.05$ significant difference from stressed mice, $\mathrm{c}, \mathrm{d}=\mathrm{p}<0.05$ significant difference from GE $(40 \mathrm{mg} / \mathrm{kg}$ ) and AG (50 mg/kg)- treated stressed mice. Veh: vehicle; IMMO: immobilization; DZP (U): diazepam (unstressed); DZP(S): diazepam (stressed) GE(U): garlic extract (unstressed); GE(S): garlic extract (stressed); $\mathbf{A G ( U ) : ~ a m i n o g u a n i d i n e ~ ( u n s t r e s s e d ) ; ~} \mathbf{A G ( S ) : ~ a m i n o g u a n i d i n e ~ ( s t r e s s e d ) . ~} 7$ NI(U): 7-nitroindazole (unstressed); 7-NI(S): 7-nitroindazole (stressed). Doses mentioned are in mg/kg.

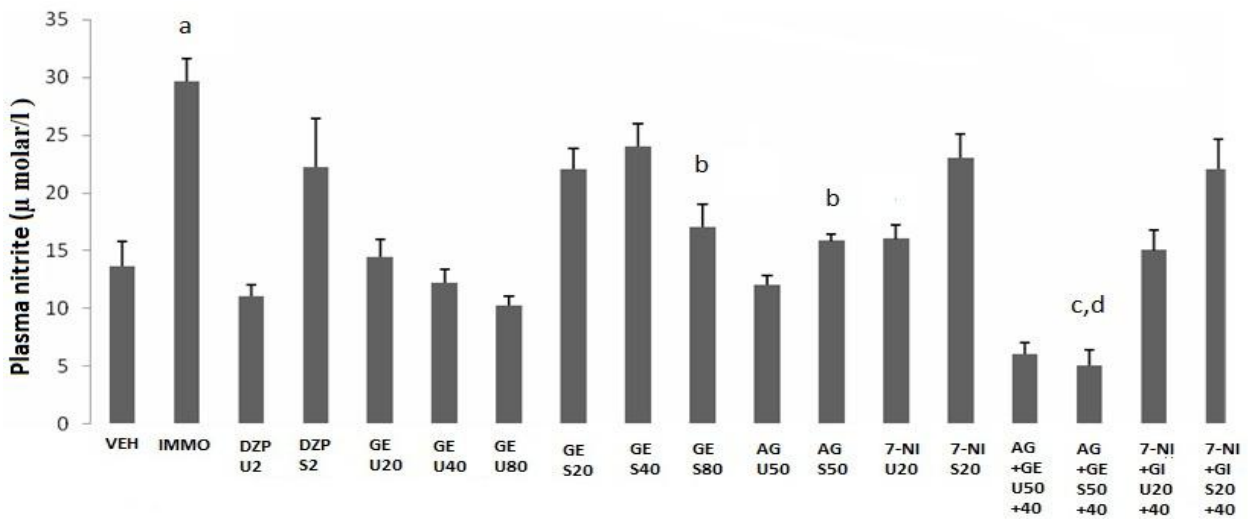

Fig. 5: Effect of different treatments on plasma nitrite levels.

$\mathrm{n}=6$ in each group. Values expressed as Mean \pm S.E., Data was analyzed by ANOVA followed by Tukey's Post hoc Test, $F(17,90)=11.78 ; \mathrm{P}<0.0001$, a $=\mathrm{p}$ $<0.05$ significant difference from vehicle treated control group, $\mathrm{b}=\mathrm{p}<0.05$ significant difference from stressed mice, $\mathrm{c}, \mathrm{d}=\mathrm{p}<0.05$ significant difference from AG $(50 \mathrm{mg} / \mathrm{kg})$ and GE (40 mg/kg)- treated stressed mice. Veh: vehicle; IMMO: immobilization; DZP (U): diazepam (unstressed); DZP(S): diazepam (stressed) GE(U): garlic extract (unstressed); GE(S): garlic extract (stressed); $\mathbf{A G ( U ) : ~ a m i n o g u a n i d i n e ~ ( u n s t r e s s e d ) ; ~} \mathbf{A G ( S ) : ~ a m i n o g u a n i d i n e ~ ( s t r e s s e d ) . ~} 7$ -

NI(U): 7-nitroindazole (unstressed); 7-NI(S): 7-nitroindazole (stressed). Doses mentioned are in mg/kg.

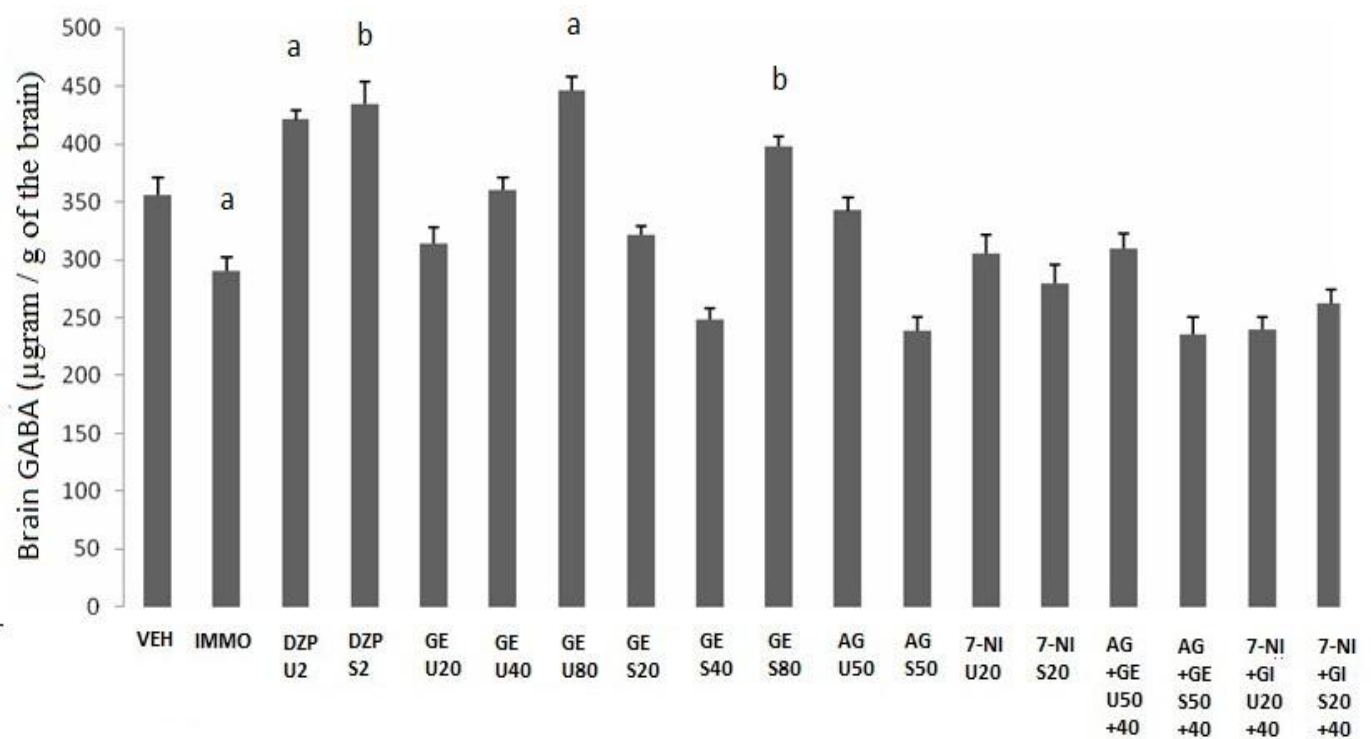

Fig. 6: Effect of different treatments on brain GABA levels.

$\mathrm{n}=6$ in each group. Values expressed as Mean \pm S.E., Data was analyzed by ANOVA followed by Tukey's Post hoc Test, $F(17,90)=29.12 ; \mathrm{P}<0.0001, \mathrm{a}=\mathrm{p}$ $<0.05$ significant difference from vehicle treated control group, $\mathrm{b}=\mathrm{p}<0.05$ significant difference from stressed mice. Veh: vehicle; IMMO: immobilization; DZP (U): diazepam (unstressed); DZP(S): diazepam (stressed) GE(U): garlic extract (unstressed); GE(S): garlic extract (stressed); AG(U): aminoguanidine (unstressed); $\mathbf{A G ( S ) : ~ a m i n o g u a n i d i n e ~ ( s t r e s s e d ) . ~ 7 - N I ( U ) : ~ 7 - n i t r o i n d a z o l e ~ ( u n s t r e s s e d ) ; ~ 7 - N I ( S ) : ~ 7 - n i t r o i n d a z o l e ~ ( s t r e s s e d ) . ~ D o s e s ~ m e n t i o n e d ~ a r e ~ i n ~ m g / k g . ~}$ 
unstressed mice in light compartment, but not in case of stressed mice. GE $(80 \mathrm{mg} / \mathrm{kg})$ produced a significant antianxiety-like activity in unstressed as well as stressed mice. AG $(50 \mathrm{mg} / \mathrm{kg})$ per se, significantly increased percentage of time spent in light compartment by stressed mice as compared to vehicle- treated stressed mice, but not in unstressed mice. Pre-treatment with AG $(50 \mathrm{mg} / \mathrm{kg})$ significantly enhanced antianxiety effect of GE (40 $\mathrm{mg} / \mathrm{kg}$ ) in stressed mice as compared to GE (40 mg/kg) as well as AG $(50 \mathrm{mg} / \mathrm{kg})$ alone in stressed mice, but not in unstressed mice. $7-\mathrm{NI}(20 \mathrm{mg} / \mathrm{kg})$ per se significantly produced anti-anxiety activity in unstressed mice, but not in stressed mice. Pre-treatment with 7NI $(20 \mathrm{mg} / \mathrm{kg})$ did not produced any significant change in antianxiety- like activity of GE (40 mg/kg) in unstressed and stressed mice (Fig. 3).

In social interaction test, $6 \mathrm{~h}$ immobilization significantly decreased percentage of time spent by mice in social interaction as compared to vehicle- treated unstressed mice. Diazepam $(2 \mathrm{mg} / \mathrm{kg})$ significantly increased percentage of time spent in social interaction by unstressed mice, but not by stressed mice. GE ( 80 $\mathrm{mg} / \mathrm{kg}$ ) produced a significant antianxiety- like activity in unstressed as well as stressed mice. AG $(50 \mathrm{mg} / \mathrm{kg})$ per se, produced a significant antianxiety- like activity in stressed mice, but not in unstressed mice. Pre- treatment with AG $(50 \mathrm{mg} / \mathrm{kg})$ significantly enhanced antianxiety effect of GE $(40 \mathrm{mg} / \mathrm{kg})$ in stressed mice as compared to GE (40 mg/kg) as well as AG (50 $\mathrm{mg} / \mathrm{kg}$ ) alone in stressed mice, but not in unstressed mice. 7-NI (20 $\mathrm{mg} / \mathrm{kg}$ ) per se, significantly produced anti-anxiety activity in unstressed mice, but not in stressed mice. Pre-treatment with 7-NI $(20 \mathrm{mg} / \mathrm{kg})$ did not produced any significant change in antianxietylike activity of GE $(40 \mathrm{mg} / \mathrm{kg})$ in unstressed and stressed mice (Fig. 4).

Immobilization stress significantly increased plasma nitrite levels in stressed mice, as compared to vehicle- treated unstressed mice. Diazepam (2 $\mathrm{mg} / \mathrm{kg})$ did not produce any significant change in plasma nitrite levels in both unstressed and stressed mice. GE $(20,40$ or $80 \mathrm{mg} / \mathrm{kg})$ did not produce any change in basal plasma nitrite levels in unstressed mice as compared to vehicle- treated unstressed mice. In stressed mice, only high dose of GE $(80 \mathrm{mg} / \mathrm{kg})$ significantly attenuated the immobilization stress- induced increase in plasma nitrite levels. AG $(50 \mathrm{mg} / \mathrm{kg})$ per se administration did not produce any significant change in plasma nitrite levels in unstressed mice as compared to that in vehicle- treated unstressed mice, but it significantly decreased immobilization- induced increase in plasma nitrite levels in stressed mice. Further, pre-treatment with AG $(50 \mathrm{mg} / \mathrm{kg})$ significantly decreased plasma nitrite levels in GE (40 $\mathrm{mg} / \mathrm{kg}$ ) - treated stressed mice as compared to mice, treated with GE (40 mg/kg) and AG (50 mg/kg) alone. 7-NI $(20 \mathrm{mg} / \mathrm{kg})$ per se, did not produce any significant change in plasma nitrite levels in both unstressed and stressed mice as compared to their respective vehicle- treated controls. Similarly, pre-treatment with $7-\mathrm{NI}(20 \mathrm{mg} / \mathrm{kg})$ in $\mathrm{GE}(40 \mathrm{mg} / \mathrm{kg})$ - treated stressed mice did not produce any significant change in plasma nitrite levels, as compared to that in stressed mice treated with GE $(40 \mathrm{mg} / \mathrm{kg})$ and 7-NI (20 mg/kg) alone (Fig. 5).

Immobilization stress significantly lowered brain GABA content in stressed mice as compared to vehicle- treated unstressed mice. Diazepam ( $2 \mathrm{mg} / \mathrm{kg}$ ) significantly enhanced the brain GABA content in unstressed as well as stressed mice as compared to respective vehicle- treated controls. GE $(80 \mathrm{mg} / \mathrm{kg})$ significantly increased brain GABA content in unstressed as well as stressed mice. AG and 7-NI per se failed to produce any change in brain GABA levels in unstressed as well as stressed mice. Further, Pretreatments with AG $(50 \mathrm{mg} / \mathrm{kg})$ and $7-\mathrm{NI}(20 \mathrm{mg} / \mathrm{kg})$ failed to bring any change in GABA levels in brains of unstressed as well as stressed mice, treated with GE (40 mg/kg) (Fig. 6).

None of the drug treatment was able to produce any significant change in locomotor activity, so results are not shown here.

\section{DISCUSSION}

Forced immobilization is one of the best explored models of stress in rats. As painful stimuli are not directly involved in restraint stress, this form of stress is probably more akin to physiological stress (Bhattacharya and Bhattacharya, 1982). Therefore, we have used physical immobilization for $6 \mathrm{~h}$ as stressor for mice and found that stress exposed mice were more anxious in their behavior as compared to unstressed mice (Gilhotra and Dhingra, 2009; 2011; Sharma et al., 2011). Further, immobilization stress, as used in the present study, is reported to increase expression of iNOS in brain cortex and leads to production of the stable nitric oxide metabolites (nitrite and nitrate) in both plasma and brain (Madrigal et al., 2002; Lee et al., 2007) and plasma nitrite levels are found to increase significantly in mice, exposed to $6 \mathrm{~h}$ immobilization stress (Gilhotra and Dhingra, 2009; 2011; Sharma et al., 2011). On the other hand, reports exploring the effect of longer stress on animal behavior are not consistent, rather contradictory to each other; for example, $72 \mathrm{~h}$ sleep-deprived mice showed an anxiogenic behavior in elevated plus maze (Kumar and Singh, 2008) and opposite results were found by another study (Pokk and Vali, 2002), indicating reduced anxiety in mice induced by $24 \mathrm{~h}$ small platform stress.

Diazepam $(2 \mathrm{mg} / \mathrm{kg})$ produced significant anxiolytic- like effect in unstressed mice, but could not exert significant anxiolysis in stressed mice. This effect is independent of its effect on locomotor activity, as noticed in the present study and also supported by the literature (Kurt et al., 2004). This observation is supported by our earlier reports (Gilhotra and Dhingra, 2011). Recently, Sharma et al. have reported the observed the underlying nitriergic influence, responsible for this compromised effect of diazepam in stressed mice (Sharma et al., 2011). GE $(80 \mathrm{mg} / \mathrm{kg})$ produced a significant anti-anxiety activity in unstressed mice, which was accompanied by a significant increase in brain GABA content. Agents, that act as agonists of GABA receptors (known as GABA analogues or GABAergic drugs) or increase the available amount of GABA typically have relaxing, anti-anxiety and anticonvulsive effects (Chapouthier and Venault, 2001; Foster and 
Camp, 2006). GE (80 mg/kg) also showed significant antianxiety effect in stressed mice, which was accompanied by a significant increase in brain GABA content and a significant decrease in plasma nitrite levels. This effect may be attributed to inhibitory effect on NO production (Schwartz et al., 2002), since, stressor (6h immobilization), used in the present study, leads to increase in expression of NO through activation of iNOS and AG, an inhibitor of iNOS, is observed to show anxiolytic- like activity (Madrigal $e t$ al., 2002; Gilhotra and Dhingra, 2009). Further, garlic is also reported to inhibit the iNOS and NF-кB (Youn et al., 2005). To date, there is not even a single report regarding protective effect of garlic in anxiety under unstressed and stressed conditions in mice. We have explored the possible impact of iNOS and NF-кB inhibiting property of GE on anxiety, using $6 \mathrm{~h}$ immobilizationinduced anxiety model; that involve TNF, NF-KB and iNOS (Madrigal et al., 2002) and furthermore, iNOS inhibitor (Gilhotra and Dhingra, 2009) and NF-KB inhibitor (Gilhotra and Dhingra, 2009; Sharma et al., 2011) have shown antianxiety- like activities in the above said model. In addition, GABA modulation property of garlic was also investigated in anxiety condition, keeping in mind that GABA modulators play an established therapeutic role in anxiety (Shwartz et al. 2005) and drugs, that act as agonists of GABA receptors (known as GABA analogues or GABAergic drugs) or increase the available amount of GABA typically have relaxing, anti-anxiety and anti-convulsive effects (Chapouthier and Venault, 2001; Foster and Kemp, 2006). In the present study, the noted antianxiety effect of GE was accompanied by a significant attenuation of immobilization-induced increase in plasma nitrite levels in stressed mice. Acute immobilization-induced increase in plasma nitrite levels is reported to be decreased by AG, a selective iNOS inhibitor (Gilhotra and Dhingra, 2009). Here, in the present study, the expression of antianxiety- like effect of GE in mice under stressed conditions and enhancement of this effect by pretreatment with $\mathrm{AG}$ as compared to $\mathrm{AG}$ and $\mathrm{GE}$ alone, indicate the role of iNOS in the noted antianxiety effect of GE. It is noteworthy that 7-NI, a selective nNOS inhibitor did not produced any change in the antianxiety- like activity of GE in unstressed as well as stressed mice. 7-nitroindazole per se has produced antianxiety-like effect in unstressed mice and failed to do so in stressed mice. Though, expression of nNOS is also found to increase after restraint stress (De Oliviera et al., 2000). But, nNOS is more sensitive to autoinhibitory effects of NO on enzyme activity (Griscavage et al., 1995). 7-Nitroindazole has also failed to block the stress-induced hippocampal NOS activation (Harvey et al., 2004). It is also advocated that overproduction of NO following stress more likely involve iNOS and not nNOS. Further, increased nNOS expression following restraint stress may be more effectively targeted by 7-nitroindazole under conditions of severe stress (Harvey et al., 2004), and may not do so in acute stress, used in the present study. In the present study, selective inhibitor of different isoforms of NOS i.e. AG (inhibitor of iNOS) and 7-NI (inhibitor of nNOS) have produced antianxiety- like activities. However, they have produced differential effects in unstressed and stressed mice; AG, showing antianxiety- like activity in stressed mice and 7-NI, showing antianxiety- like activity in unstressed mice. These observations are supported by our earlier observations on these agents in the same model (Gilhotra et al., 2010). Further, when given as pretreatment 7-nitroindazole did not significantly enhance the effect of GE $(40 \mathrm{mg} / \mathrm{kg})$, suggesting the noninvolvement of nNOS in antianxiety-like effect of GE in unstressed and stressed mice.

In addition to changes in nitrite levels, $6 \mathrm{~h}$ immobilization stress also produced a significant decrease in brain GABA content. Diazepam $(2 \mathrm{mg} / \mathrm{kg})$ significantly increased the brain GABA content in unstressed as well as stressed mice. Similarly, GE (80 $\mathrm{mg} / \mathrm{kg}$ ) has been able to increase the brain GABA content in unstressed as well as stressed mice. However, antianxiety- like effects of GE $(80 \mathrm{mg} / \mathrm{kg})$ and diazepam $(2 \mathrm{mg} / \mathrm{kg})$ are not exerted equally in both unstressed and stressed mice; GE $(80 \mathrm{mg} / \mathrm{kg})$ producing antianxiety- like activity in both unstressed and stressed mice, while diazepam $(2 \mathrm{mg} / \mathrm{kg})$, producing antianxiety- like activity in only unstressed mice. In unstressed mice, GE $(80$ $\mathrm{mg} / \mathrm{kg})$ - and diazepam $(2 \mathrm{mg} / \mathrm{kg})$ - induced increases in GABA content may be responsible for their significant antianxiety- like effect, which may further be attributed to the absence of a strong nitriergic influence in unstressed mice, as compared to strong nitriergic influence, observed in stressed mice (Sharma et al., 2011). The absence of nitriergic influence in unstressed mice has also been demonstrated in other reports (Gilhotra et al., 2010). The observed pattern of behavioral and biochemical effects of GE and diazepam under unstressed and stressed conditions further suggests that the nitriergic stimulus in stressed mice is sufficient to disturb benzodiazepine-GABA receptor function. These observations are strengthened by earlier reports of disturbance in benzodiazepine-GABA receptor function by stressful stimuli, including immobilization (Boix et al., 1988; Weizman et al., 1990).

Observed insignificant effects of GE, diazepam, AG, 7NI on locomotor activity suggested the negligible interference of locomotion in observed behavior of mice in behavioral paradigms.

\section{CONCLUSION}

In conclusion, the above study suggests the garlic may exert antianxiety- like activity in mice by increasing GABA content and overcoming nitriergic influence on GABAergic environment, as evident by enhancement of the effect of GE by NOS inhibitors in unstressed and stressed mice.

\section{REFERENCES}

Baeza-Raja B, Munoz-Canoves P. p38 MAPK-induced nuclear factor-kappaB activity is required for skeletal muscle differentiation: role of interleukin-6. MolBiol Cell, 2004; 15(4):2013-2026.

Bhattacharya SK,Bhattachatya D. Effect of restraint stress on rat brain serotonin. J Biosci, 1982; 4(3):269-274.

Boix F, Fernandez TA, Tobea A. The anxiolytic action of benzodiazepines is not present in handling- habituated rats. Pharmacol Biochem Behav, 1988; 31(3):541-546.

Calatayud F, Belzung C, Aubert, A. Ethological validation and the assessment of anxiety- like behaviours: methodological comparison of 
classical analyses and structural approaches. Behav Proc, 2004; 67(2):195206.

ChapouthierG,Venault P. Pharmacological link between epilepsy and anxiety? Trends Pharmacol Sci, 2001; 22(10):491-493.

Chauhan NB, Sandoval J. Amelioration of early cognitive deficits by aged garlic extract in Alzhiemer's transgenic mice. Phytother Res, 2007; 21(7):629-640.

Crawley J, Goodwin FK. Preliminary report of a simple animal behavior model for the anxiolytic effects of benzodiazepines. Pharmacol Biochem Behav, 1980; 13(2):167-170.

De Oliviera RM, Aparecida DBE, Mameda-Rosa ML, Padovan $\mathrm{CM}$, Deakin JF, GuimaraesFS. Expression of neuronal nitric oxide synthase mRNA in stress-related brain areas after restraint in rats.Neurosci Lett, 2000; 289(2):123-126.

Dhingra D, Kumar V. Evidence for the involvement of monoaminergic and GABAergic systems in anti-depressant-like activity of garlic extract in mice. Ind J Pharmacol, 2008; 40(4):175-179.

Esch T, Stefano GB, Fricchione GL, Benson H. The role of stress in neurodegenerative diseases and mental disorders. Neuroendocrinol Lett, 2002; 23(3):199-208.

File SE. The use of social interaction as a method for detecting anxiolytic activity of chlordiazepoxide-like drugs. J Neurosci Methods, 1980; 2(3):219-238

Fiore M, Alleva E, Probert L, Kollias G, Angelucci F, Aloe L. Exploratory and displacement behavior in transgenic mice expressing high levels of TNF- $\alpha$. PhysiolBehav, 1998; 63(4):571.

Foster AC, Kemp JA. Glutamate- and GABA-based CNS therapeutics. Curr Opin Pharmacol, 2006; 6(1):7-17.

Gilhotra N, Dhingra D. GABAergic and nitriergic modulation by curcumin for its antianxiety-like activity in mice. Brain Res, 2010; 1352(9):167-175.

Gilhotra N, Dhingra D. Thymoquinone produced antianxietylike effects in mice through modulation of GABA and NO levels. Pharmacol Rep, 2011; 63(3):660-669.

Gilhotra N, Dhingra D. Involvement of NO-cGMP pathway in anti-anxiety effect of aminoguanidine in stressed mice. Prog Neuropsychopharmacol Biol Psychiatry, 2009; 33(8):1502-1507.

Gilhotra N, Jain H, Dhingra D. Differential effects of nitric oxide synthase inhibitors on anxiety in unstressed and stressed mice. Ind $\mathrm{J}$ ExpBiol, 2010; 48(4):365-372.

Green LC, Wagner DA, Glogowski J, Skipper PL, WishnockJS,Tannenbaum SR. Analysis of Nitrate, nitrite, and [N-15N]labelled nitrate in biological fluids. Ann Biochem1982; 126(1):131-138.

Griscavage JM, Hobbs AJ, IgnarroLJ. Negative modulation of NOS by NO and nitroso compounds. Ad Pharmacol, 1995; 34:215-234.

Harvey BH, Oosthuizen F, Brand L, Wegener G, Stein DJ. Stress-restress evokes sustained iNOS activity and altered GABA levels and NMDA receptors in rat hippocampus. Psychopharmacol, 2004; 175(4):494-502.

Heinrichs SC, Menzanghi F, Pich EM, Baldwin HA, Rassnick S, Britton KT. Anti-stress action of corticotrophin-releasing factor antagonist on behavioral reactivity to stressors of varying types and intensity. Neuropsychopharmacol, 1994; 11(3):179-186.

Ide N, Nelson AB, Lau BHS. Aged garlic extract and its constituents inhibit $\mathrm{Cu}(2+)$-induced oxidative modification of low density lipoprotein. Planta Med, 1997; 63(3):263-264.

Imai J, Ide N, Nagae S, Moriguchi T, Matsuura H, Itakura Y. Antioxidant and radical scavenging effects of aged garlic extract and its constituents. Planta Med,1994; 60(5):417-420.

Kulkarni SK. Handbook of Experimental Pharmacology. Delhi, VallabhPrakashan, 1999.

Kumar A, Singh A. Possible nitric oxide modulation in protective effect of (Curcuma longa, Zingiberaceae) against sleep deprivation-induced behavioral alterations and oxidative damage in mice. Phytomed, 2008; 15(8):577-586.

Kurt M, Bilge SS, Aksoz E, Kukula O, Celik S, Kesim Y. Effect of sildenafill on anxiety in the plus-maze test in mice. Pol J Pharmacol, 2004; 56(3):353-357.
Kyo E, Uda N, Kasuga S, Itakura Y. Immunomodulatory effects of aged garlic extract. J Nutr,2001; 131(3s):1075S-1079S.

Kyo E, Uda N, Ushijima M, KasugaS,Itakura Y. Prevention of psychological stress-induced immune suppression by aged garlic extract. Phytomed, 1999; 6(5):325-330.

Lee CY, Cheng HM,Sim SM 2007. Mulberry leaves protect rat tissues from immobilization stress-induced inflammation. Biofactors, 2007; 31(1):25-33.

Lowe IP, Robins E, Eyerman GS. Thefluorimetric measurement of glutamic decarboxylase and its distribution in brain. J Neurochem, $1958 ; 3(1): 8-16$

Madrigal JL Olivia HO, Moro MA, Lizasoain I, Lorenzo $\mathrm{P}$, Castrillo A. The increase in TNF- $\alpha$ Levels is implicated in NF- $\kappa \mathrm{B}$ activation and inducible nitric oxide synthase expression in brain cortex after immobilization stress. Neuropsychopharmacol,2002;26(2):155-163.

Manzanares PAR, Isoardi NA, Carrer HF, Molina VA. Previous stress facilitates fear memory, attenuates GABAergic inhibition, and increases synaptic plasticity in the rat basolateral amygdala. J Neurosci, 2005; 25(38):8725-8734.

Masood A, Banerjee B, Vijayan VK, Ray A. Modulation of stress-induced neurobehavioral changes by nitric oxide in rats. Eur J Pharmacol, 2003; 458(1-2):135-139.

Nagao K, Takenaka S, Yamaji R, Inui H, Nakano Y. Nitric oxide synthase induction, cGMP elevation, and biopterin synthesis in vascular smooth muscle cells stimulated with interleukin-1beta in hypoxia. J Biochem, 2003; 133(4):501-505.

Perez-Severiano F, Rodriguez-Perez M, Pedraza-Chaverri J, Maldonado PD, Medina-Campos ON, Ortiz-Plata A, Sanchez-Garcia A, Villeda-Hernandez J, Galvan-Arzate S, Aguilera P,Santamaria A. SAllylcysteine, a garlic-derived antioxidant, ameliorates quinolinic acidinduced neurotoxicity and oxidative damage in rats. Neurochem Intern, 2004; 45(8):1175-1183.

PokkP,Vali M. The effects of the nitric oxide synthase inhibitors on the behaviour of small-platform-stressed mice in the plusmaze test. Prog Neuropsychopharmacol Biol Psychiatry, 2002; 26(2):241247.

Pokk P, Sepp E, Vassiljev V, Vali M. The effects of the nitric oxide synthase inhibitor 7-nitroindazole on the behaviour of mice after chronic ethanol administration. Alcohol Alcohol, 2001; 36(3):193-198.

Saglam B, Cikler E, Zeybek A, Cetinel S, Sener G, Ercan F. An aqueous garlic extract alleviates water avoidance stress-induced degeneration of the urinary bladder. Br J UrolInt, 2006; 98(6):1250-1254.

Saleem S, Ahmad M, AhmadAS, Yousuf S, Ansari MA, Khan $\mathrm{MB}$, Ishrat $\mathrm{T}$, Islam $\mathrm{F}$. Behavioral and histologic neuroprotection of aqueous garlic extract after reversible focal cerebral ischemia. J Med Food, 2006; 9(4):537-544.

Schwartz IF, Hershkovitz R, Iaina A, Gnessin E, Wollman Y, Chernichowski T, Blum M, Levo Y, Schwartz D. Garlic attenuates nitric oxide production in rat cardiac myocytes through inhibition of inducible nitric oxide synthase and the arginine transporter CAT-2 (cationic amino acid transporter-2). ClinSci, 2002; 102(5):487-493.

Schwartz TL, Nihalani N, Simionescu M, Hopkins G. History Repeats Itself: Pharmacodynamic Trends in the Treatment of Anxiety Disorders. Curr Pharm Des, 2005; 11(2): 255-263.

Sevgi S, Ozek M, Eroglu L. L-NAME prevent anxiety-like and depression-like behavior in rats exposed to restraint stress. Methods Find ExpClinPharmacol, 2006; 28(2):95-99.

Sharma V, Gilhotra R, Dhingra D, Gilhotra N. Possible underlying influence of $\mathrm{p} 38 \mathrm{MAPK}$ and NF-KB in diminished anti-anxiety effect of diazepam in stressed mice. J PharmacolSci2011; 116(3):257-263.

Sumioka I, Matsura T, Yamada K. Therapeutic effect of Sallylmercaptocysteine on acetaminophen-induced liver injury in mice.Eur J Pharmacol,2001; 433(2-3):177-185.

The Wealth of India.A dictionary of Indian raw materials and industrial products. New Delhi, Council of Scientific and Industrial Research, 1985.

Ushijima M, Sumioka I, Kakimoto M, Yokoyama K, Uda N, Matsuura H. Effect of garlic, and garlic preparations on physiological and 
psychological stress in mice. Phytother Res, 1997; 11(3):226-230.

Vercammen E, Staal J, Van Den Broeke A, Haegman M, Vereecke L, Schotte P, Beyaert R. Prolonged exposure to IL-1beta and IFN gamma induces necrosis of L929 tumor cells via a p38MAPK-NF-кBNO dependent mechanism. Oncogene,2008; 27(27):3780-3788.

Wang BH, Zuzel KA, Rahman K, Billington D. Treatment with aged garlic extract protects against bromobenzene toxicity to precision cut rat liver slices. Toxicol,1999; 132(2-3):215-225.

Weizman AM, Bidder FF, Gavish M. Food deprivation modulates gamma-butyric acid receptors and peripheral benzodiazepine binding sites in rats. Brain Res, 1990; 535(1):96-100.

Youn HS, Lim HJ, Lee HJ, Hwang D, Yang M, Jeon R, Ryu JH. Garlic (Allium sativum) Extract Inhibits Lipopolysaccharide- induced Toll-Like Receptor 4 Dimerization. Biosci Biotechnol Biochem,2005; 72(2):368-375.

\section{How to cite this article:}

Neeraj Gilhotra, Dinesh Dhingra. GABAergic and nitriergic influence in antianxiety-like Activity of Garlic in Mice. J App Pharm Sci, 2016; 6 (04): 077-085. 